\title{
ANALISIS FAKTOR-FAKTOR YANG MEMENGARUHI PRESTASI MAHASISWA DI PERGURUAN TINGGI
}

\section{Rahardian Okta Pratama, Lindawati Kartika, \& Andita Sayekti \\ e-mail: rahardianokta2310@gmail.com Institut Pertanian Bogor}

\author{
Jl. Raya Dramaga Kampus IPB Dramaga Bogor, Jawa Barat 16680
}

\begin{abstract}
Abstrak: IPB berada pada empat besar peringkat Kementerian Riset dan Pendidikan Tinggi selama tiga tahun berturut-turut, namun IPB masih memiliki peringkat kemahasiswaan yang terendah dibandingkan tiga universitas lain dalam peringkat tersebut. Salah satu komponen nilai kemahasiswaan adalah prestasi mahasiswa. Penelitian ini bertujuan untuk (1) mengidentifikasi karakteristik mahasiswa yang berprestasi, (2) menganalisis persepsi mengenai faktor-faktor yang memengaruhi prestasi mahasiswa, (3) menganalisis pengaruh antara faktor-faktor yang memengaruhi prestasi mahasiswa terhadap prestasi mahasiswa, (4) mengidentifikasi Net Promoter Score alumni terhadap IPB. Studi kasus pada penelitian ini adalah alumni Departemen Manajemen FEM IPB. Penelitian dilaksanakan di lingkungan Institut Pertanian Bogor yang berada di Bogor, Jawa Barat dengan mengambil target objek penelitian adalah alumni Program Sarjana Departemen Manajemen IPB dengan jalur reguler angkatan 2009-2013. Waktu pelaksanaan penelitian ini dilaksanakan pada bulan Januari 2018 sampai April 2018. Data yang digunakan dalam penelitian ini adalah data primer dan sekunder. Metode yang digunakan adalah analisis deskriptif, SEM-PLS, dan Net Promoter Score. Hasil penelitian ini menunjukkan bahwa faktor lingkungan memiliki nilai T-statistik 2.053, fisiologis memiliki nilai T-statistik 2.031, psikologis memiliki nilai T-statistik 2.701, dan instrumental memiliki nilai T-statistik 0.033 . Berdasarkan hal tersebut maka faktor lingkungan, fisiologis, dan psikologis memengaruhi prestasi mahasiswa secara signifikan.
\end{abstract}

Kata-kata kunci: mahasiswa, pendidikan tinggi, prestasi, SEM PLS

\section{ANALYSIS OF FACTORS THAT AFFECTING STUDENT ACHIEVEMENT IN HIGHER-EDUCATION}

\begin{abstract}
IPB is consistently becoming the Top 4 Best Universities based on the result of The Ministry of Research and Higher-Education Assessment Score for three years. Meanwhile, IPB still has the lowest assessment score on student affairs among other three universities. One of the significant components is the student achievements. This research aim (1) to identify the characteristics of the excellent students, (2) to analyze the perceptions about factors that significantly affect student achievement and student achievement itself, (3) to analyze the factors that significantly affect student achievement and student achievement itself, (4) to determine the result of Net Promoter Score of alumni to IPB. This research focused on a case of Department of Management Alumni Graduates of 2009 - 2013 FEM IPB that was conducted in Bogor Agricultural University from January to April 2018. This research used both primary and secondary data. The data analysis of this research was conducted by descriptive analysis, SEM-PLS, and Net Promoter Score. This research resulted that the environmental, physiological, psychological and instrumental factors had a -statistic as orderly followed by 2.053, 2.031, 2.701, 0.033, whereas these factors were concluded to significantly affect the students`achievement.
\end{abstract}

Keywords: achievement, student, higher education, SEM PLS

\section{PENDAHULUAN}

Perguruan tinggi yang baik akan mampu meningkatkan kualitas sumber daya manusia. Pendidikan menjadi sebuah hal yang penting untuk mendapatkan sumber daya manusia yang unggul dan berkualitas (Putri, 2014). Perguruan tinggi sebagai jenjang pendidikan yang sangat penting dimana sumber daya manusia benar-benar disiapkan dalam menghadapi persaingan di era saat ini. Perguruan tinggi adalah lembaga pendidikan yang diharapkan peranannya secara signifikan dalam mencerdaskan 
kehidupan bangsa untuk menunjang pembangunan sumber daya manusia menuju masyarakat yang maju, sehingga mampu bersaing dengan bangsabangsa lain (Purba, 2009). Selain pemeringkatan kualitas pendidikan tinggi secara global, di dalam negeri pun perguruan tinggi berlomba-lomba untuk menunjukkan kualitasnya. Tabel 1 yang menunjukkan pemeringkatan perguruan tinggi berdasarkan Kementerian Riset dan Pendidikan Tinggi Indonesia.

Tabel 1

Empat Besar Peringkat Perguruan Tinggi Terbaik di Indonesia Berdasarkan Kemenristekdikti 2015-2017

\begin{tabular}{clccc}
\hline No & \multicolumn{1}{c}{ Nama PTN } & Peringkat 2015 & Peringkat 2016 & Peringkat 2017 \\
\hline 1 & $\begin{array}{l}\text { Institut Teknologi } \\
\text { Bandung }\end{array}$ & 1 & 1 & 2 \\
2 & $\begin{array}{l}\text { Universitas Gadjah } \\
\text { Mada }\end{array}$ & 2 & 2 & 1 \\
3 & $\begin{array}{l}\text { Institut Pertanian } \\
\text { Bogor }\end{array}$ & 3 & 4 & 3 \\
4 & $\begin{array}{l}\text { U n i v e r s i t a s } \\
\text { Indonesia }\end{array}$ & 4 & 3 & 4
\end{tabular}

Sumber: Kementerian Riset dan Pendidikan Tinggi Indonesia (2017)

Berdasarkan tabel 1, tertera empat besar peringkat perguruan tinggi terbaik di Indonesia pada periode tahun 2015-2017. Peringkat yang dikeluarkan oleh Kementerian Riset dan Pendidikan Tinggi Indonesia didasarkan pada empat aspek yakni kualitas sumber daya manusia, penelitian dan publikasi, manajemen/ kelembagaan/akreditasi, dan yang terakhir adalah kemahasiswaan. Empat besar perguruan tinggi selama 3 tahun selalu ditempati oleh Institut Teknologi Bandung, Universitas Gadjah Mada, Institut Pertanian Bogor, dan Universitas Indonesia. Institut Pertanian Bogor menempati peringkat 3 di tahun 2015, peringkat 4 di tahun 2016, dan meningkat menjadi peringkat 3 di tahun 2017. Hal tersebut menunjukkan bahwa Institut Pertanian Bogor secara institusi sudah memiliki kualitas yang baik.

Mahasiswa adalah kelompok pemangku kepentingan internal yang harus mendapatkan manfaat dan sekaligus sebagai pelaku proses pembentukan nilai tambah dalam penyelenggaraan kegiatan/program akademik yang bermutu tinggi di program studi sarjana (BAN-PT, 2008). Selain layanan akademik, mahasiswa perlu mendapatkan layanan pengembangan minat dan bakat dalam bidang spiritual, seni budaya, olahraga, kepekaan sosial, pelestarian lingkungan hidup, serta bidang kreativitas lainnya. Aspek kemahasiswaan juga tidak lepas dalam menentukan baik atau tidaknya perguruan tinggi. Semakin baik, kualitas kemahasiswaannya maka dapat memberikan dukungan terhadap kualitas dari perguruan tinggi tersebut. Gambar 1 merupakan nilai dari aspek kemahasiswaan pada empat besar perguruan tinggi negeri terbaik di Indonesia yang dikeluarkan oleh Kementerian Riset dan Pendidikan Tinggi Indonesia.

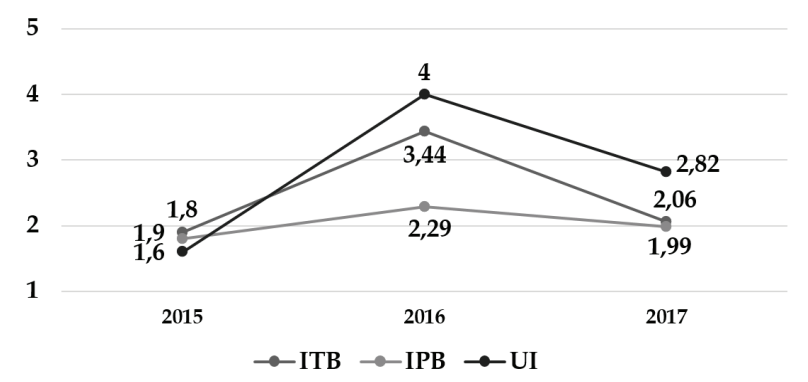

Gambar 1. Nilai aspek kemahasiswaan empat besar perguruan tinggi terbaik di Indonesia pada tahun 2015-2017

(Sumber: Kementerian Riset dan Pendidikan Tinggi Indonesia, 2017)

Gambar 1 menyajikan nilai aspek kemahasiswaan pada empat besar perguruan tinggi terbaik di Indonesia pada tahun 2015-2017. Institut Pertanian Bogor memiliki nilai kemahasiswaan terkecil dibanding dengan tiga universitas yang lain. Hal ini tentu menjadi sebuah tugas bagi Institut Pertanian Bogor untuk meningkatkan kualitas aspek kemahasiswaan yang masih jauh tertinggal, padahal secara peringkat kualitas perguruan tingginya sudah bagus.

Upaya peningkatan aspek kemahasiswaan tidak terlepas dari faktor prestasi yang diraih oleh mahasiswa itu sendiri. Prestasi mahasiswa dapat dilihat dari segi prestasi akademik seperti peraihan IPK, keikutsertaan dalam program kreativitas mahasiswa, dan lomba karya tulis ilmiah. Selain itu, prestasi mahasiswa juga dapat dilihat dari prestasi nonakademik seperti keikutsertaan dalam lomba seni maupun olahraga. Kementerian Riset dan Pendidikan Tinggi Indonesia juga setiap tahunnya mengadakan ajang pemilihan mahasiswa berprestasi di tingkat nasional. Mahasiswa berprestasi dapat dinilai dari beberapa aspek yaitu kemampuan akademik, kemampuan bahasa, kemampuan leadership, pengembangan karakter, keikutsertaan dalam lomba atau kegiatan tingkat nasional maupun internasional, dan kemampuan berkomunikasi (Kemenristekdikti, 2017).

Program Sarjana Manajemen Fakultas Ekonomi dan Manajemen Institut Pertanian Bogor (FEM IPB) didirikan pada tahun 2000 telah memiliki alumni sebanyak empat belas angkatan hingga tahun 2018. Program studi ini memiliki empat bidang peminatan 
yaitu pemasaran, sumber daya manusia, keuangan, dan produksi operasi. Melalui salah satu misi dari departemen manajemen, yaitu melaksanakan pendidikan tinggi standar internasional manajemen untuk menghasilkan lulusan dengan kompetensi yang tinggi dalam manajemen, dilengkapi dengan keterampilan untuk komunikasi, organisasi, dan kewirausahaan. Lulusan Manajemen IPB harus memiliki prestasi yang baik dalam menghadapi persaingan yang semakin kompetitif. Indikator prestasi bisa dilihat dari pencapaian IPK dan pencapaian dalam lomba-lomba yang diikuti oleh mahasiswa. Gambar 2 merupakan rataan IPK lulusan Departemen Manajemen dari lima angkatan terakhir yakni angkatan 2009-2013.

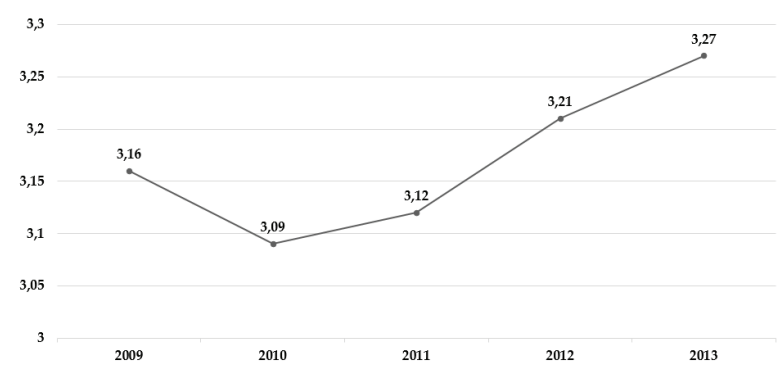

Gambar 2. Data rataan IPK Departemen Manajemen angkatan 2009-2013

(Sumber: Departemen Manajemen FEM IPB, 2017)

Gambar 2 menunjukkan rataan IPK dari angkatan 2009-2013. Dari skala 4, rataan IPK dari mahasiswa departemen manajemen masih berada di sekitar angka tiga. Secara grafik, telah terjadi peningkatan sejak angkatan 2010 hingga 2013. Hal ini menunjukkan bahwa ada peningkatan prestasi akademik berupa IPK dari lulusan departemen manajemen. Selanjutnya, pada Gambar 3 akan ditampilkan grafik prestasi mahasiswa departemen manajemen yang diperoleh pada periode tahun 20132017.

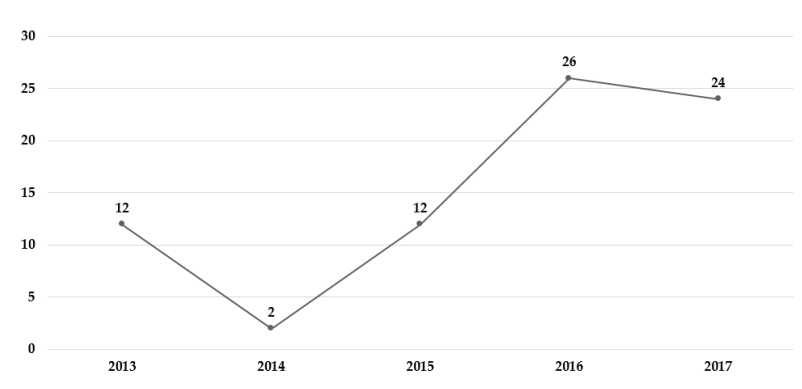

Gambar 3. Pencapaian prestasi mahasiswa manajemen pada tahun 2013-2017

(Sumber: Departemen Manajemen FEM IPB, 2017)

Berdasarkan gambar 3 dapat dilihat bahwa tren pencapaian prestasi mahasiswa departemen manajemen belum stabil. Pencapaian prestasi mahasiswa departemen manajemen masih mengalami pasang surut. Selain itu, rasio mahasiswa departemen manajemen yang berprestasi dibandingkan dengan jumlah seluruh mahasiswa pada periode 2016 hingga 2017 berada pada angka 2.6\%. Angka tersebut masih berada di bawah angka rasio IPB yang berada pada angka 3.6\% berdasarkan data dari Direktorat Kemahasiswaan IPB. Hal ini menjadi tantangan tersendiri bagi departemen manajamen untuk lebih konsisten dan meningkatkan lagi prestasi mahasiswanya.

Guna meningkatkan kualitas SDM melalui bidang pendidikan khususnya di perguruan tinggi ternyata banyak faktor yang memengaruhi keberhasilannya. Situasi yang sangat berpengaruh seperti adanya perbedaan lingkungan belajar, gaya belajar, lingkungan kampus, sarana dan prasarana pendidikan, serta karakteristik dosen dan mahasiswa. Faktor-faktor tersebut dapat berpengaruh terhadap keberhasilan studi mahasiswa baik secara langsung maupun tidak langsung. Peningkatan kualitas pendidikan pada perguruan tinggi tentu akan dapat meningkatkan kepuasan mahasiswa. Kepuasan mahasiswa merupakan hal yang sangat penting karena mahasiswa merupakan konsumen utama dari perguruan tinggi. Semakin banyak mahasiswa yang puas maka citra perguruan tinggi tersebut akan semakin baik.

Oleh karena itu, penelitian mengenai faktorfaktor yang memengaruhi prestasi mahasiswa menjadi menarik untuk dilakukan. Maka dalam penelitian ini dilakukan analisis terkait faktor-faktor yang memengaruhi prestasi mahasiswa dengan studi kasus alumni departemen manajemen.

Perbedaan penelitian ini dengan beberapa penelitian terdahulu terletak pada objek yang akan diteliti dan variabel prestasi yang digunakan. Penelitian ini mengambil objek pada mahasiswa yang memenuhi kriteria mahasiswa yang berprestasi, mengingat fokus utama penelitian ini adalah terkait dengan prestasi mahasiswa. Hal tersebut tidak dilakukan pada penelitian-penelitian terdahulu yang tidak memberikan kriteria terhadap mahasiswa yang menjadi objek. Dengan adanya kriteria yang ditetapkan pada objek penelitian ini, maka hasil yang diharapkan terhadap penelitian terkait prestasi mahasiswa lebih valid daripada penelitian-penelitian terdahulu. Pada penelitian ini akan digunakan variabel prestasi yang mengacu pada kriteria mahasiswa berprestasi nasional yang dikeluarkan oleh Kementerian Riset dan 
Pendidikan Tinggi yang sudah diakui secara nasional. Kriteria mahasiswa berprestasi menurut panduan mahasiswa berprestasi Ditmawa IPB merujuk pada panduan pemilihan mahasiswa berprestasi nasional oleh Kementerian Riset dan Pendidikan Tinggi pada tahun 2017, terdiri dari (1) kemampuan akademik. Kemampuan akademik dilihat dari Indeks Prestasi Kumulatif (IPK). IPK minimal 3.00 bisa menjadi acuan karena IPK tersebut juga menjadi salah satu prasyarat yang umum digunakan untuk melamar beasiswa atau pekerjaan. Nilai minimum IPK tersebut merupakan nilai rata-rata yang menjadi acuan bahwa seorang mahasiswa mampu mengikuti proses pembelajarannya; (2) kemampuan bahasa. Komunikasi yang baik tentu didukung pula oleh kemampuan bahasa yang baik.

Seorang mahasiswa setidaknya harus dapat menguasai minimal satu bahasa PBB (Inggris, Spanyol, Arab, Mandarin, Perancis, dan Rusia) dengan bobot terbesar adalah bahasa Inggris; (3) kemampuan leadership. Kemampuan memimpin seseorang menentukan tingkat keefektifan pribadi maupun organisasi yang dipimpinnya. Kemampuan ini tidak hanya berorientasi pada tugas yang diemban akan tetapi juga hubungan antar manusia yang lain; (4) pengembangan karakter, karakter tersebut dapat mencerminkan bahwa seorang mahasiswa memiliki sosok yang religious yang berarti mahasiswa memiliki iman dan takwa kepada Tuhan Yang Maha Esa dan menjadikan agama sebagai motivasi dalam meningkatkan kapasitas diri dan bermanfaat bagi orang lain; (5) keikutsertaan lomba dan kegiatan tingkat nasional.

Melalui keikutsertaan lomba maupun kegiatan nasional mahasiswa mendapatkan banyak keuntungan. Pertama, mahasiswa mendapatkan bekal lebih mengenai cara penulisan suatu karya tulis maupun kreativitas yang diunggulkan misalnya fotografi, menyanyi, bermain alat musik, maupun menari daerah. Kedua, mahasiswa juga memiliki kepercayaan diri yang cukup karena sudah terlatih untuk berbicara di depan publik baik saat debat maupun presentasi; (6) keikutsertaan lomba dan kegiatan tingkat internasional. Lomba dan kegiatan internasional akan melatih mahasiswa untuk meraih pengalaman yang sangat berharga. Seorang mahasiswa bisa menjadi delegasi bagi kampusnya dan tentunya delegasi bagi negara. Seorang mahasiswa bisa berinteraksi dengan delegasi dari berbagai negara dalam satu acara; dan (7) kemampuan berkomunikasi. Komunikasi bukan hanya masalah berbicara tapi juga tentang menuangkan ide melalui tulisan. Selain itu, kemampuan yang dimaksudkan adalah kemampuan berkomunikasi dihadapan publik (public speaking) dan kemampuan berkomunikasi melalui tulisan.

Faktor-faktor yang memengaruhi proses dan hasil belajar berasal dari dalam dan dari luar individu (Purwanto, 2013). Faktor yang berasal dari luar yaitu lingkungan dan instrumental, sedangkan faktor dari dalam individu terbagi atas fisiologis dan psikologis. Faktor-faktor tersebut memiliki masing-masing subfaktor. Lingkungan terbagi menjadi dua jenis lingkungan, yakni lingkungan alam dan lingkungan sosial. Instrumental terbagi menjadi empat yakni kurikulum, pengajar, sarana dan fasilitas, serta administrasi. Selanjutnya, fisiologis terbagi menjadi dua yakni kondisi fisik dan kondisi panca indera. Terakhir, psikologis terbagi menjadi lima yakni bakat, minat, kecerdasan, motivasi, dan kemampuan kognitif.

\section{METODE PENELITIAN}

Penelitian ini dilaksanakan di lingkungan Institut Pertanian Bogor dengan mengambil target objek penelitian adalah alumni Program Sarjana Departemen Manajemen IPB dengan jalur reguler angkatan 2009-2013. Waktu pelaksanaan penelitian ini dilaksanakan pada bulan Januari 2018 - April 2018.

Data yang digunakan dalam penelitian ini meliputi data primer dan sekunder. Data primer yang digunakan melalui kuesioner, sedangkan data sekunder berupa database alumni Program Sarjana Departemen Manajemen IPB angkatan 2009-2013, data-data akademik Departemen Manajemen FEM IPB, penelitian-penelitian terdahulu, dan berbagai literatur yang lain berupa online maupun offline.

Jumlah sampel yang diambil dalam penelitian ini ditentukan menurut rumus Lemeshow. Rumus tersebut dipilih karena dirasa cocok untuk penelitian dengan populasi yang tidak pasti (Lemeshow et al, 1990). Setelah melalui perhitungan bahwa jumlah sampel minimum yang diambil adalah 70 orang. Metode pengambilan sampel yang dilakukan menggunakan non-probability sampling dengan teknik purposive sampling dan network sampling. Dalam penelitian ini, ada dua kriteria yang disyaratkan kepada responden yakni (1) memiliki IPK di atas 3.00 dan (2) memiliki prestasi nasional atau internasional. Teknik purposive sampling dengan dua syarat di atas dipilih agar menunjukkan responden merupakan mahasiswa yang berprestasi. Network sampling digunakan agar peneliti memiliki kemudahan untuk mendapatkan responden. Total sampel yang diambil sebanyak 72 orang telah memenuhi jumlah sampel 
dari perwakilan masing-masing angkatan.

Metode analisis yang digunakan dalam penelitian ini adalah analisis deskriptif, SEM-PLS dan Net Promoter Score. Analisis deskriptif berfungsi untuk mendeskripsikan atau memberi gambaran terhadap objek yang diteliti melalui data sampel atau populasi sebagaimana adanya. Analisis deskriptif dilakukan dengan penyajian data, dengan tabel biasa maupun distribusi frekuensi; grafik garis maupun batang; diagram lingkaran; pictogram; penjelasan kelompok melalui modus, median, mean, dan variasi kelompok melalui rentang dan simpangan baku. Penelitian ini akan menggunakan penilaian persepsi melalui 4 skala likert dengan rentang nilai sebagai berikut.

$$
\text { Rentang Nilai }=\frac{(\text { nilai maksimum }- \text { nilai minimum })}{\text { nilai maksimimum }}
$$

Dari perhitungan rentan nilai dengan skala likert 1-4 makan diperoleh jarak sebesar 0,75. Hasil perhitungan skala penilaian persepsi dapat dilihat pada tabel 2.

Tabel 2

Skala Penilaian Persepsi

\begin{tabular}{ccl}
\hline No & Nilai & \multicolumn{1}{c}{ Skala } \\
\hline 1 & $1-1,75$ & Sangat Tidak Setuju \\
2 & $1,75-2,5$ & Tidak Setuju \\
3 & $2,5-3,25$ & Setuju \\
4 & $>3,25$ & Sangat Setuju \\
\hline
\end{tabular}

Sumber: Data diolah (2018)

Skala penilaian persepsi di atas akan digunakan untuk melihat serta menilai persepsi responden terhadap variabel-variabel yang digunakan. Penilaian persepsi responden ini menjelaskan indikator yang paling berpengaruh dalam pembentukan variabel.

Analisis SEM-PLS menggunakan dua evaluasi yakni evaluasi outer model dan inner model. Evaluasi outer model reflektif dilakukan pada first order. Evaluasi berdasarkan tiga kriteria yaitu convergent validity, discriminant validity, dan composite reliability, sedangkan pengujian inner model ada dua kriteria yaitu R-square pada konstruk first order untuk mengidentifikasi kategori model dan path coefisien untuk pengujian hipotesis (Ghozaly, 2014). Metode SEM-PLS terdiri dari dua jenis variabel yakni variabel laten dan variabel manifes. Variabel laten biasa disebut inner model dan variabel manifes biasa disebut outer model.

Metodologi net promoter score pada intinya adalah mengajukan kepada responden tentang seberapa besar kemungkinan responden untuk merekomendasikan perusahaan/pekerjaan ini kepada teman atau koleganya (Survey Monkey, 2017). Responden menilai jawaban mereka pada skala dari 0-10. Jawaban responden diklasifikasikan di gambar 4.

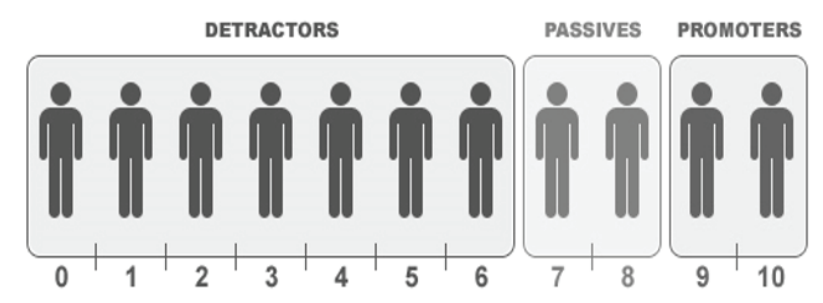

Gambar 4. Klasifikasi responden untuk net promoter score (Sumber: Monkey, 2017)

Dari gambar 4 dapat dilihat klasifikasinya adalah (1) detractors yaitu yang memiliki skor 0-6 dan merupakan responden yang tidak puas; (2) passives yaitu yang memiliki skor 7-8, merupakan responden yang cukup puas namun masih acuh tak acuh; dan (3) promoters yaitu yang memiliki skor 9-10 merupakan responden yang sangat puas dan akan merekomendasikan pekerjaannya kepada orang lain. Cara menghitung net promoter score adalah sebagai berikut.

Net Promoter Score $=\%$ Promoters $-\%$ Detractors

\section{HASIL DAN PEMBAHASAN}

Karakteristik Alumni yang Berprestasi di Departemen Manajemen

Responden dalam penelitian ini sebanyak 72 orang yang berasal dari alumni Departemen Manajemen FEM IPB sebanyak 5 angkatan, yakni angkatan tahun 2009-2013 yang memenuhi kriteria. Karakteristik responden dibedakan menjadi dua jenis yakni karakteristik responden semasa kuliah dan pada tahun 2018. Karakteristik semasa kuliah merupakan karakteristik yang melekat kepada responden selama berkuliah S1 di Departemen Manajemen FEM IPB. Alumni yang berprestasi, memiliki IPK terbanyak pada rentang 3.26-3.50. Pencapaian prestasi baik tingkat nasional maupun internasional didominasi oleh pencapaian prestasi di bidang penalaran. Hal tersebut memperlihatkan bahwa tidak hanya IPK yang menjadi fokus alumni dalam pencapaian prestasi namun prestasi-prestasi lainnya juga dapat diraih dengan tetap mempertahankan IPK yang baik. Jalur penerimaan IPB didominasi melalui jalur undangan tanpa tes dikarenakan IPB selalu memberikan prioritas terbesar pada jalur tersebut. Hal tersebut tepat, dikarenakan alumni berprestasi terbanyak berasal dari jalur undangan tanpa tes sebanyak 69\%. Mayoritas 
alumni yang berprestasi juga menerima beasiswa ketika kuliah di S1.

Pendapatan alumni berprestasi terbanyak berada pada rentang Rp 3.700.000-Rp 7.400.000 per bulan yakni sebesar $49 \%$. Hal tersebut sesuai dengan profesi alumni berprestasi saat ini yakni 58\% alumni berprofesi sebagai karyawan swasta, dengan rentang usia berada pada angka 21-28 tahun sehingga usia alumni manajemen pada angkatan 2009-2013 yang berprestasi tergolong usia muda dan produktif. Tabel 3 merupakan tabel tabulasi silang antara karakteristik IPK dan keaktifan mengikuti organisasi selama kuliah.

Tabel 3

Tabulasi Silang IPK dan Organisasi Ketika Kuliah

\begin{tabular}{|c|c|c|c|c|c|c|c|}
\hline & & \multicolumn{5}{|c|}{ Organisasi (orang) } & \multirow[b]{2}{*}{ Total } \\
\hline & & UKM & $\begin{array}{c}\text { B E M / } \\
\text { DPM }\end{array}$ & HIMPRO & $\begin{array}{c}\text { Komunitas/ } \\
\text { Paguyuban }\end{array}$ & $\underset{\text { Ikut }}{\operatorname{Tid} \text { ak }}$ & \\
\hline \multirow[t]{3}{*}{ IPK } & $\begin{array}{l}\text { I P K : } \\
3.01- \\
3.25\end{array}$ & 4 & 3 & 9 & 1 & 2 & 19 \\
\hline & $\begin{array}{l}\text { I P K : } \\
3.26- \\
3.50\end{array}$ & 2 & 5 & 14 & 7 & 2 & 30 \\
\hline & $\begin{array}{l}\text { IPK: > } \\
3.50\end{array}$ & 4 & 5 & 10 & 3 & 1 & 23 \\
\hline \multicolumn{2}{|c|}{ Total } & 10 & 13 & 33 & 11 & 5 & 72 \\
\hline
\end{tabular}

Sumber: Data diolah (2018)

Berdasarkan Tabel 3 dapat dilihat bahwa mahasiswa berprestasi mayoritas juga berperan aktif mengikuti organisasi di kampus, hanya 5 orang saja yang tidak aktif mengikuti organisasi.

Data tersebut menunjukkan bahwa dengan aktif berorganisasi para alumni masih dapat mempertahankan IPK yang baik. Dapat disimpulkan bahwa dengan berorganisasi bukanlah menjadi penghalang bagi mahasiswa untuk tetap aktif dalam berorganisasi Selanjutnya, akan dilakukan tabulasi silang antara IPK dengan profesi saat ini. Tabel 4 merupakan tabel tabulasi silang antara IPK dengan profesi saat ini.

Tabel 4

Tabulasi Silang IPK dan Profesi Saat Ini

\begin{tabular}{|c|c|c|c|c|c|c|c|c|c|}
\hline \multicolumn{9}{|c|}{ Profesi (orang) } & \multirow{2}{*}{ Total } \\
\hline & $\begin{array}{c}\text { Mahasiswa } \\
\text { S2 }\end{array}$ & $\begin{array}{l}\text { Karyawan } \\
\text { Swasta }\end{array}$ & $\begin{array}{l}\text { PNS/ } \\
\text { BUMN }\end{array}$ & $\begin{array}{l}\text { Wira- } \\
\text { usaha }\end{array}$ & $\begin{array}{l}\text { Profe- } \\
\text { sional }\end{array}$ & BUMD & IRT & $\begin{array}{l}\text { Belum } \\
\text { Bekerja }\end{array}$ & \\
\hline $\begin{array}{l}\text { IPK: } \\
3.01- \\
3.25\end{array}$ & 0 & 11 & 3 & 2 & 2 & 1 & 0 & 0 & 19 \\
\hline $\begin{array}{l}\text { IPK: } \\
3.26- \\
3.50\end{array}$ & 2 & 18 & 8 & 1 & 0 & 0 & 1 & 0 & 30 \\
\hline $\begin{array}{l}\text { IPK: } \\
\text { > } \\
3.50\end{array}$ & 2 & 13 & 6 & 0 & 0 & 0 & 1 & 1 & 23 \\
\hline Total & 4 & 42 & 17 & 3 & 2 & 1 & 2 & 1 & 72 \\
\hline
\end{tabular}

Sumber: Data diolah (2018)

Berdasarkan tabel 4, dapat dilihat terdapat satu orang alumni yang belum bekerja padahal alumni tersebut memiliki IPK yang sangat baik yakni pada rentang IPK $>3.50$. Hal ini dapat menunjukkan bahwa tidak ada jaminan jika memiliki IPK yang tinggi mempermudah untuk mendapat pekerjaan di pascakampusnya.

Selanjutnya, akan ditabulasi silang kembali terkait karakteristik IPK dengan penghasilan saat ini. Tabel 5 merupakan tabel tabulasi silang antara IPK dengan penghasilan saat ini.

Tabel 5

Tabulasi Silang IPK dan Profesi Saat Ini

\begin{tabular}{|c|c|c|c|c|c|c|c|c|}
\hline \multicolumn{8}{|c|}{ Penghasilan (Rupiah) } & \multirow{2}{*}{ Total } \\
\hline & $\underset{3.700 .000}{<}$ & $\begin{array}{l}3.700 .000- \\
7.400 .000\end{array}$ & $\begin{array}{l}7.400 .001- \\
11.100 .000\end{array}$ & $\begin{array}{l}11.100 .001- \\
14.800 .000\end{array}$ & $\begin{array}{l}14.800 .001- \\
18.500 .000\end{array}$ & $\begin{array}{l}18.500 .001- \\
22.2000 .000\end{array}$ & $\stackrel{>}{22.200 .000}$ & \\
\hline $\begin{array}{l}\text { IPK: } \\
3.01- \\
3.25\end{array}$ & 2 & 11 & 4 & 0 & 0 & 1 & 1 & 19 \\
\hline $\begin{array}{l}\text { IPK: } \\
3.26- \\
3.50\end{array}$ & 6 & 14 & 7 & 1 & 1 & 1 & 0 & 30 \\
\hline $\begin{array}{l}\text { IPK: > } \\
3.50\end{array}$ & 9 & 10 & 2 & 0 & 0 & 2 & 0 & 23 \\
\hline Total & 17 & 35 & 13 & 1 & 1 & 4 & 1 & 72 \\
\hline
\end{tabular}

Sumber: Data diolah (2018)

Perhitungan penghasilan yang mengacu pada angka 3.700.000 didasarkan pada UMR daerah DKI Jakarta. Ada dua hal yang menarik berdasarkan data di atas, yang pertama adalah pada rentang gaji terendah yaitu $<3.700 .000$ terbanyak dimiliki oleh alumni yang memiliki IPK paling tinggi yakni pada rentang IPK $>3.50$ sebanyak 9 orang. Hal kedua yang menarik adalah pada rentang gaji tertinggi yakni $>22.000 .000$ dimiliki oleh satu orang alumni yang memiliki rentang IPK terendah yakni IPK 3.01-3.25. Kedua hal tersebut tentunya dapat menunjukkan bahwa tidak adanya hubungan yang selalu positif antara IPK dengan penghasilan saat ini. Hal ini berarti bahwa tidak ada jaminan bahwa seseorang yang memiliki IPK yang tinggi akan otomatis ketika pascakampusnya akan memiliki penghasilan yang tinggi juga. Berdasarkan beberapa pembahasan dengan menggunakan tabulasi silang di atas dapat ditunjukkan bahwa IPK bukanlah segalanya yang menjamin kehidupan pascakampus mahasiswa.

Persepsi Alumni Departemen Manajemen FEM IPB terhadap Lingkungan, Instrumental, Fisiologis, Psikologis dan Prestasi

Alumni Manajemen FEM IPB memiliki persepi mengenai variabel lingkungan, instrumental, fisiologis, psikologis, dan prestasi. Pada bagian ini akan melihat serta membahas terkait persepsi dari alumni Departemen Manajemen FEM IPB dengan pendekatan analisis deskriptif terhadap variabel-variabel yang diteliti dalam penelitian ini. Untuk lebih jelasnya dapat 
dilihat pada tabel 6 .

Tabel 6

Persepsi Alumni Departemen Manajemen FEM IPB terhadap Lingkungan, Instrumental, Fisiologis, Psikologis, dan Prestasi

\begin{tabular}{|c|c|c|}
\hline Pernyataan & Nilai & Keterangan \\
\hline \multicolumn{3}{|l|}{ LINGKUNGAN } \\
\hline Lingkungan Alam & 2.72 & Mendukung \\
\hline Lingkungan Sosial & 3.64 & Sangat Mendukung \\
\hline \multicolumn{3}{|l|}{ INSTRUMENTAL } \\
\hline Kurikulum & 3.10 & Mendukung \\
\hline Pengajar & 3.29 & Sangat Mendukung \\
\hline Sarana dan Fasilitas & 2.99 & Mendukung \\
\hline $\begin{array}{l}\text { Administrasi/ } \\
\text { Manajemen }\end{array}$ & 3.11 & Mendukung \\
\hline \multicolumn{3}{|l|}{ FISIOLOGIS } \\
\hline Kondisi Fisik & 3.14 & Mendukung \\
\hline Kondisi Panca Indra & 3.32 & Sangat Mendukung \\
\hline \multicolumn{3}{|l|}{ PSIKOLOGIS } \\
\hline Bakat & 3.63 & Sangat Mendukung \\
\hline Minat & 3.31 & Sangat Mendukung \\
\hline Kecerdasan & 3.51 & Sangat Mendukung \\
\hline Motivasi & 3.40 & Sangat Mendukung \\
\hline Kemampuan Kognitif & 3.51 & Sangat Mendukung \\
\hline \multicolumn{3}{|l|}{ PRESTASI } \\
\hline Kemampuan Akademik & 2.95 & Setuju \\
\hline Kemampuan Bahasa & 2.85 & Setuju \\
\hline Kemampuan Leadership & 3.39 & Sangat Setuju \\
\hline Pengembangan Karakter & 3.19 & Setuju \\
\hline $\begin{array}{l}\text { Keikutsertaan Lomba dan } \\
\text { Kegiatan Nasional }\end{array}$ & 3.08 & Setuju \\
\hline $\begin{array}{l}\text { Keikutsertaan Lomba dan } \\
\text { Kegiatan Internasional }\end{array}$ & 2.72 & Setuju \\
\hline $\begin{array}{l}\text { Kemampuan } \\
\text { Berkomunikasi }\end{array}$ & 3.21 & Setuju \\
\hline
\end{tabular}

Keterangan: Angka yang berwarna biru merupakan nilai terbesar dan yang berwarna merah merupakan nilai terkecil (Sumber: Data diolah, 2018).

Variabel lingkungan yang dipersepsikan paling mendukung untuk berprestasi adalah indikator lingkungan sosial. Variabel instrumental yang dipersepsikan paling mendukung untuk berprestasi adalah indikator pengajar. Variabel fisiologis yang dipersepsikan paling mendukung untuk berprestasi adalah kondisi panca indra. Variabel psikologis yang dipersepsikan paling mendukung untuk berprestasi adalah indikator bakat, sedangkan pada variabel prestasi, alumni beranggapan sangat setuju bahwa indikator kemampuan leadership terbentuk selama berkuliah di Departemen Manajemen FEM IPB.

Analisis Faktor Eksternal dan Internal yang Memengaruhi Prestasi Mahasiswa dengan Pendekatan Partial Least Square (PLS)

Penelitian ini bertujuan untuk menganalisis faktor-faktor yang memengaruhi prestasi mahasiswa.

Masing-masing variabel memiliki nilai yang berbedabeda. Analisis ini digunakan untuk melihat bentuk dan pengaruh langsung variabel laten eksogen yaitu lingkungan, instrumental, fisiologis, dan psikologis terhadap variabel laten endogen yaitu prestasi. Desain penelitian dalam SEM ini terdiri dari lima variabel laten dan 20 variabel manifes. Variabel laten tersebut terdiri dari lingkungan, instrumental, fisiologis, psikologis, dan prestasi. Berikut merupakan model awal dari penelitian ini pada gambar 5 .

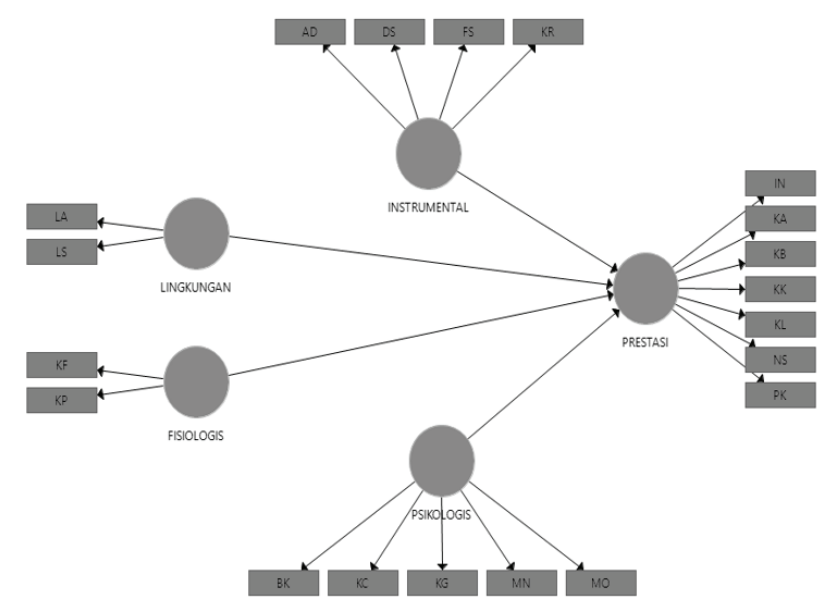

Gambar 5. Desain struktural variabel laten dan indikator pada permodelan awal (Sumber: Data diolah, 2018)

Analisis ini terdiri dari dua tahapan. Tahap pertama adalah evaluasi outer model yang terdiri tiga subtahap yakni convergent validity, discriminant validity, dan composite reability. Tahap kedua adalah evaluasi inner model yang terdiri dari nilai $R^{2}$ menggunakan PLS Algoritm dan path coefficient estimation dengan menggunakan bootstraping. Berikut tabel 7 merupakan ringkasan tahapan SEM-PLS.

Tabel 7

Hasil Evaluasi Outer Model dan Inner Model SEM-PLS

\begin{tabular}{|c|c|c|c|}
\hline Kriteria & Standar Penilaian & Realisasi Nilai & Ket \\
\hline $\begin{array}{l}\text { Convergent } \\
\text { Validity } \\
\text { (Outer } \\
\text { Model) }\end{array}$ & Nilai loading factor $>0.70$ & $\begin{array}{l}\text { Indikator yang direduksi } \\
\text { bernilai di bawah } 0.70 \text { sebanyak } \\
7 \text { indikator dari } 20 \text { indikator }\end{array}$ & M \\
\hline $\begin{array}{l}\text { Discriminant } \\
\text { Validity } \\
\text { (Outer } \\
\text { Model) }\end{array}$ & $\begin{array}{l}\text { 1. Nilai crossloading variabel } \\
\text { latennya }>\text { variabel laten } \\
\text { lainnya } \\
\text { 2. Nilai akar kuadrat AVE } \\
\text { setiap konstruk }>\text { nilai } \\
\text { korelasi antara konstruk } \\
\text { dengan konstruk lainnya } \\
\text { 3. Nilai AVE }>0.50\end{array}$ & $\begin{array}{l}\text { Nilai crossloading, nilai akar } \\
\text { kuadrat AVE, serta nilai AVE } \\
\text { setiap variabel sudah memenuhi } \\
\text { standar. }\end{array}$ & M \\
\hline $\begin{array}{l}\text { Composite } \\
\text { Reability } \\
\text { (Outer } \\
\text { Model) }\end{array}$ & $\begin{array}{l}\text { Nilai composite reability > } \\
0.70\end{array}$ & $\begin{array}{l}\text { Fisiologis }(0.937) \\
\text { Instrumental }(0.868) \\
\text { Lingkungan }(0.870) \\
\text { Psikologis }(0.864) \\
\text { Prestasi }(0.907)\end{array}$ & M \\
\hline $\begin{array}{l}\text { Original } \\
\text { Sample } \\
\text { (Inner } \\
\text { Model) }\end{array}$ & $\begin{array}{l}\text { Angka }(+) \text { memiliki } \\
\text { pengaruh positif langsung } \\
\text { Angka (-) tidak memiliki } \\
\text { pengaruh positif langsung }\end{array}$ & $\begin{array}{l}\text { Lingkungan > > Prestasi }(0.204) \\
\text { Instrumental > > Prestasi }(-0.003) \\
\text { Fisiologis > > Prestasi }(0.286) \\
\text { Psikologis > > Prestasi }(0.329)\end{array}$ & $\begin{array}{l}\mathrm{M} \\
\mathrm{M} \\
\mathrm{M} \\
\mathrm{M}\end{array}$ \\
\hline $\begin{array}{l}\text { Signifikansi } \\
\quad \text { (Inner } \\
\text { Model) }\end{array}$ & Nilai T-Statisik > $1.66(10 \%)$ & $\begin{array}{l}\text { Lingkungan >> Prestasi }(2.053) \\
\text { Instrumental }>>\text { Prestasi }(0.033) \\
\text { Fisiologis >> Prestasi }(2.031) \\
\text { Psikologis >> Prestasi }(2.701)\end{array}$ & $\begin{array}{l}\mathrm{M} \\
\mathrm{TM} \\
\mathrm{M} \\
\mathrm{M}\end{array}$ \\
\hline
\end{tabular}




\begin{tabular}{cccc}
\hline Kriteria & Standar Penilaian & \multicolumn{1}{c}{ Realisasi Nilai } & Ket \\
\hline $\begin{array}{c}\text { Nilai } \mathrm{R}^{2} \\
\text { (Inner } \\
\text { Model) }\end{array}$ & $\begin{array}{l}\mathrm{R}^{2} \text { 0.67 (model kuat), 0,33 } \\
\text { (model moderat) dan 0,19 } \\
\text { (model lemah) }\end{array}$ & $\begin{array}{l}\mathrm{R}^{2} \text { kinerja sebesar 0.401 (model } \\
\text { moderat) }\end{array}$ & $\mathrm{M}$ \\
\hline
\end{tabular}

Keterangan: $\mathrm{M}=$ memenuhi, $\mathrm{TM}=$ tidak memenuhi (Sumber: Data diolah, 2018)

Berdasarkan tabel 7, model telah memenuhi semua kriteria. Hal tersebut akan menghasilkan model baru yang telah memenuhi kriteria. Gambar 6 merupakan model baru yang dihasilkan.

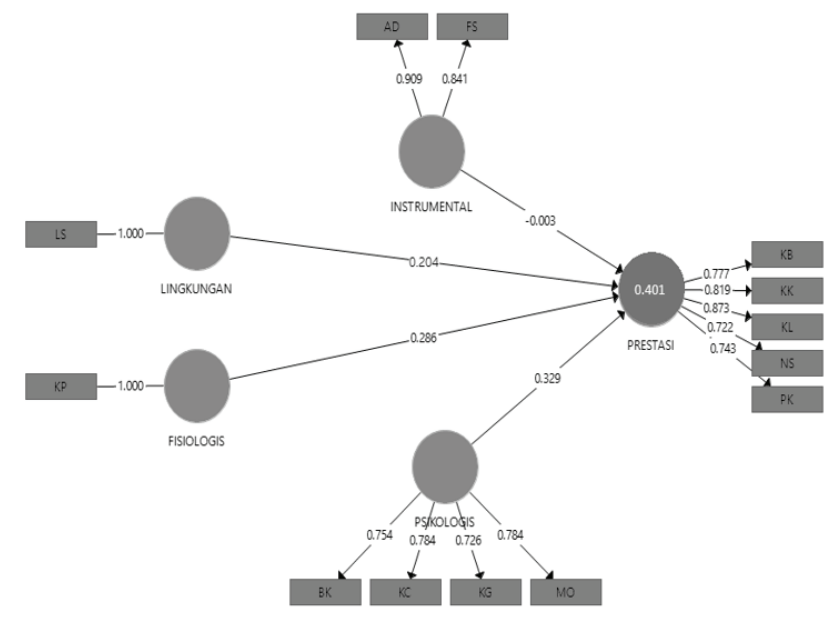

Gambar 6. Model dan perhitungan akhir (Sumber: Data diolah, 2018)

Berdasarkan gambar 6, dapat dinyatakan bahwa indikator kemampuan akademik (KA) berupa pencapaian IPK tidak dapat merefleksikan variabel prestasi dikarenakan prestasi mahasiswa, dalam hal ini, alumni departemen manajemen tidak dicerminkan oleh IPK saja. Melainkan prestasi yang sesungguhnya dapat ditunjukkan oleh ranah kemampuan leadership (KL). Selain itu, juga dicerminkan dari ranah kemampuan berkomunikasi (KK). Ranah kemampuan berbahasa $(\mathrm{KB})$ yang merupakan salah satu tuntutan menghadapi era persaingan global saat ini juga menunjukkan variabel prestasi. Pengembangan karakter (PK) juga dianggap merefleksikan variabel prestasi dan yang terakhir adalah keikutsertaan dalam lomba atau kegiatan nasional (NS). Semua kemampuan tersebut mencerminkan prestasi mahasiswa yang merupakan hasil selama proses perkuliahan di departemen manajemen dan membantu untuk diaplikasikan dalam kehidupan pasca kampus.

Indikator yang merefleksikan variabel lingkungan adalah dari ranah lingkungan sosial (LS). Hal ini menunjukkan bahwa dalam pencapaian prestasi seorang mahasiswa, orang-orang terdekat mahasiswa tersebut memiliki peranan yang besar dalam mendukung pencapaian prestasi, sedangkan lingkungan alam (LA) dianggap tidak merefleksikan variabel lingkungan.

Kondisi panca indra (KP) merupakan indikator yang merefleksikan variabel fisiologis, sedangkan untuk kondisi fisik (KF) tidak menggambarkan variabel fisiologis. Ini berarti alumni Manajemen pada umumnya lebih dapat menyerap materi yang diberikan dan proses pembelajaran dapat berjalan dengan lancar melalui kolaborasi kemampuan yang melibatkan panca indra mata, telinga, lisan serta psikomotorik diri.

Indikator yang merefleksikan variabel instrumental adalah dari ranah administrasi dan manajemen (AD). Selain itu, indikator fasilitas dan sarana (FS) juga merefleksikan variabel instrumental. Dua variabel lain yakni kurikulum (KR) dan dosen (DS) dianggap tidak merefleksikan variabel instrumental. Indikator yang merefleksikan variabel psikologis adalah dari indikator bakat (BK), kecerdasan (KC), kemampuan kognitif (KG), dan motivasi (MO).

\section{Net Promoter Score}

Dalam penelitian ini, metode ini digunakan untuk melihat loyalitas dari para alumni departemen manajemen terhadap IPB. Hal ini diharapkan akan bermanfaat bagi IPB sebagai sebuah institusi pendidikan untuk senantiasa meningkatkan dan memperbaiki kualitasnya. Berikut disajikan tabel 8 yang merupakan klasifikasi responden untuk net promoter score.

Tabel 8

Klasifikasi Responden untuk Net Promoter Score

\begin{tabular}{lcc}
\hline \multicolumn{1}{c}{ Jenis } & Jumlah & Persentase \\
\hline Promoters & 22 orang & $30.55 \%$ \\
Passive & 46 orang & $63.88 \%$ \\
Dectractor & 4 orang & $5.55 \%$ \\
\hline \multicolumn{1}{c}{ Total } & 72 orang & $100 \%$ \\
\hline
\end{tabular}

Sumber: Data diolah (2018)

Konsep perhitungan NPS adalah persentase dari promoters dikurang dengan persentase dectractor maka berdasarkan data pada tabel di atas nilai NPS yang dimiliki oleh IPB adalah 25\%. Berdasarkan data di atas, IPB masih memiliki tugas untuk meningkatkan lagi kualitasnya, hal ini ditunjukkan oleh data bahwa responden yang memiliki kriteria passive masih cukup besar yakni di angka 63.88\%. Kriteria passive menggambarkan bahwa orang tersebut belum memiliki kecondongan menjadi promoters atau dectrator. Dengan meningkatkan kualitasnya maka IPB dapat mengarahkan orang-orang dengan passive ini dapat diarahkan untuk masuk ke dalam kriteria 
promoters.

\section{Implikasi Manajerial}

Berdasarkan hasil perhitungan dan pembahasan dari Net Promoter Score, IPB harus melakukan perbaikan untuk senantiasa meningkatkan kualitas pendidikannya. Hal tersebut dilakukan karena kriteria passive masih berada pada angka yang cukup besar yakni $63.88 \%$ dan didapatkan $5.55 \%$ memiliki kriteria detractor. Dengan meningkatkan kualitasnya maka IPB dapat mengarahkan orang-orang dengan kriteria passive ini dapat diarahkan untuk masuk ke dalam kriteria promoters serta dapat meminimalisir orang dengan kriteria detractor. Hal tersebut salah satunya dapat dilakukan melalui perbaikan pada unit kerja yang terdekat dengan mahasiswa yakni departemen, dalam hal ini, adalah Departemen Manajemen FEM IPB.

Berdasarkan hasil analisis deskriptif dan SEM-PLS terdapat beberapa faktor yang memiliki pengaruh terhadap prestasi mahasiswa. Hal tersebut mendorong adanya implikasi manajerial sebagai bahan pertimbangan bagi Departemen Manajemen FEM IPB untuk meningkatkan prestasi mahasiswa agar dapat menciptakan mahasiswa dan lulusan yang unggul serta kompetitif. Implikasi manajerial akan digambarkan dengan menggunakan diagram alir. Ouput dari diagram ini adalah mendukung visi dan misi dari Departemen Manajemen FEM IPB, sedangkan input dalam diagram ini adalah hasil dari penelitian ini. Gambar 7 merupakan implikasi manajerial bagi Departemen Manajemen FEM IPB.

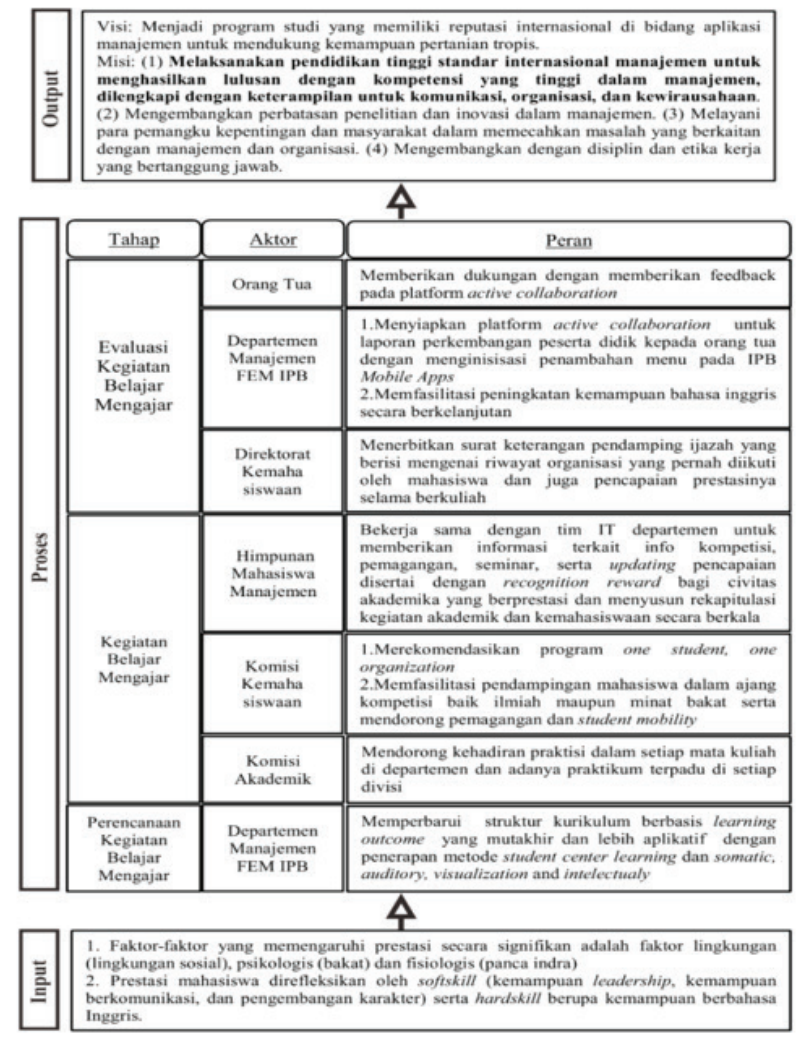

Gambar 7. Desain strategi pencapaian prestasi mahasiswa melalui diagram alir
Berdasarkan gambar 7, pada proses perencanaan kegiatan pembelajaran, Departemen Manajemen FEM IPB harus bisa mengakomodir adanya suatu struktur kurikulum yang tepat dan mutakhir. Pembelajaran yang berpusat kepada mahasiswa atau student center learning merupakan strategi yang sesuai dalam implementasi model pembelajaran berbasis soft skill (Tambunan, 2011). Selanjutnya, berdasarkan hasil penelitian variabel fisiologis yang mendukung pencapaian prestasi adalah kondisi panca indra. Model pembelajaran SAVI (somatic, auditory, visualization, dan intelectualy) merupakan model pembelajaran yang tepat untuk mendukung pengoptimalan panca indra. Model pembelajaran SAVI memadukan unsur gerak fisik dan koordinasi seluruh indra (Mirnawati dan Pribowo, 2017).

Pada tahap pelaksanaan belajar dan pembelajaran, komisi akademik mempunyai peran untuk mendorong adanya capita selecta dengan adanya guest lecture dari kalangan profesional serta adanya turun lapang terpadu pada setiap divisi. Hasil penelitian menunjukkan bahwa faktor psikologis yang perlu menjadi perhatian adalah variabel bakat utamanya pada bakat untuk memiliki kemampuan berpikir kritis dan berkolaborasi. Berpikir kritis dapat ditingkatkan melalui adanya guest lecture dan turun lapang terpadu. Kegiatan tersebut membantu untuk membuka cakrawala dan memperkaya penalaran seluruh civitas akademik. Peningkatan soft skill dapat dilakukan melaui organisasi kemahasiswaan maupun dukungan untuk kegiatan kemahasiswaan (Parma, 2014). Peran pertama yang bisa dilakukan oleh komisi kemahasiswaan adalah mendorong program one student one organization. Hal ini juga sesuai dengan program IPB yang akan menerbitkan Surat Keterangan Pendamping Ijazah (SKPI). Peran selanjutnya adalah memfasilitasi pendampingan mahasiswa dalam ajang kompetisi baik ilmiah maupun minat bakat serta mendorong pemagangan dan student mobility. Pendampingan tersebut akan mendorong semangat serta memperbaiki kualitas dari tim yang akan mengikuti kegiatan tersebut. Himpunan mahasiswa manajemen juga memiliki peranan yakni bekerja sama dengan tim IT departemen untuk memberikan informasi terkait peluang kompetisi, pemagangan, seminar, serta updating pencapaian disertai dengan recognition reward bagi civitas akademika yang berprestasi dan menyusun rekapitulasi kegiatan akademik dan kemahasiswaan secara berkala.

Tahap terakhir dari kegiatan belajar dan pembelajaran adalah tahap evaluasi. Hasil penelitian menunjukkan bahwa faktor lingkungan yang perlu menjadi perhatian adalah lingkungan sosial utamanya adalah dukungan keluarga. Keterlibatan orang tua memiliki pengaruh positif terhadap prestasi 
mahasiswa (Mailhot dan Feeney, 2017). Keterlibatan tersebut salah satunya terlihat dari komunikasi anak dan orang tua. Dengan mengetahui perkembangan anak, orang tua dapat memberikan dukungan moril apabila anak mengalami kemunduran ataupun kesulitan dalam proses belajar untuk menjaga semangat mahasiswa dalam belajar. Departemen manajemen dapat membuat platform active collaboration yang open access. Platform tersebut nantinya dapat berisi laporan perkembangan anak setiap semesternya yang terdiri dari transkrip nilai, permasalahan anak, dan prestasi yang diraih anak selama semester berjalan. Platform tersebut nantinya bisa diakses oleh orang tua mahasiswa. Salah satu cara nyata yang dapat dilakukan adalah dengan melakukan pengembangan pada IPB Mobile Apps. Selain itu, pada tahap ini, departemen manajemen dapat berperan dengan memfasilitasi peningkatan kemampuan bahasa inggris secara berkelanjutan. Hal ini sesuai dengan hasil penelitian yang menunjukkan kemampuan bahasa utamanya bahasa Inggris direfleksikan pada variabel prestasi. Peningkatan kemampuan bahasa Inggris dapat dilakukan dengan mengadakan hari berbahasa Inggris di departemen manajemen serta penyediaan fasilitas tes TOEFL bagi mahasiswa. Selanjutnya pihak yang berperan adalah direktorat kemahasiswaan, peran tersebut adalah mengeluarkan Surat Keterangan Pendamping Ijazah (SKPI).

\section{PENUTUP}

\section{Kesimpulan}

Simpulan dari hasil penelitian ini adalah sebagai berikut (1) alumni Departemen Manajemen FEM IPB angkatan 2009-2013 yang berprestasi dan menjadi responden dalam penelitian ini didominasi oleh perempuan yang sebagian besar berasal dari daerah jabodetabek. Pendapatan alumni terbanyak berada pada rentang Rp 3.700.000-Rp 7.400.000 per bulan. Mayoritas berprofesi sebagai karyawan swasta. Mayoritas aktif dalam berorganisasi semasa kuliah. Jalur masuk terbanyak melalui jalur penerimaan undangan tanpa tes; (2) variabel psikologis, fisiologis serta lingkungan sangat mendukung prestasi mahasiswa. Pada variabel lingkungan, lingkungan sosial mahasiswa merupakan hal yang sangat mendukung pencapaian prestasi. Pada variabel psikologis, bakat yang dimiliki mahasiswa merupakan hal yang sangat mendukung pencapaian prestasi. Pada variabel fisiologis, panca indra merupakan hal yang sangat mendukung pencapaian prestasi; (3) variabel psikologis, fisiologis serta lingkungan memiliki pengaruh yang signifikan terhadap prestasi mahasiswa dan variabel psikologis merupakan variabel yang memiliki nilai signifikansi paling tinggi; dan (4) hanya $25 \%$ alumni yang berperan sebagai promoter terhadap IPB.

\section{Saran}

Saran dari hasil penelitian ini adalah (1) Departemen Manajemen FEM IPB dapat melakukan beberapa cara yakni dengan memperbarui struktur kurikulum berbasis learning outcome yang mutakhir dan lebih aplikatif dengan penerapan metode student center learning dan SAVI, mendorong kehadiran praktisi dalam setiap mata kuliah di departemen dan adanya praktikum terpadu di setiap divisi, mendorong adanya program one student one organization, memfasilitasi adanya pendampingan untuk persiapan mahasiswa yang akan mengikuti perlombaan, menyiapkan platform active collaboration untuk laporan perkembangan peserta didik, memfasilitasi peningkatan kemampuan bahasa Inggris secara berkelanjutan, (2) himpunan mahasiswa manajemen (COM@) mempunyai peran dengan bekerja sama dengan tim IT departemen untuk memberikan informasi terkait info kompetisi, pemagangan, seminar, serta updating pencapaian disertai dengan recognition reward bagi civitas akademika yang berprestasi dan menyusun rekapitulasi kegiatan akademik dan kemahasiswaan, (3) orang tua mahasiswa memiliki peran dalam mendorong peningkatan prestasi mahasiswa dengan memberikan dukungan kepada anak dan memberikan feedback pada platform active collaboration, dan (4) penelitian selanjutnya disarankan untuk dapat melakukan studi komparatif dengan judul analisis faktor-faktor yang memengaruhi prestasi mahasiswa pada dua objek institusi yang berbeda. Selain itu, dapat juga dilakukan penelitian secara sensus dengan judul analisis faktor- faktor yang memengaruhi prestasi mahasiswa dengan teknik sensus pada alumni Departemen Manajemen FEM IPB.

\section{DAFTAR PUSTAKA}

BAN-PT. (2008). Naskah akademik akreditasi program studi sarjana. Jakarta: Kemenag.

Ditmawa. (2017). Panduan mahasiswa berprestasi Institut Pertanian Bogor. Bogor: Direktorat Kemahasiswaan IPB.

Ghozali, I. (2014). Structural equation modeling metode alternatif dengan partial least square (PLS). Semarang: Badan Penerbit UNDIP.

Kemenristekdikti. (2017). Pedoman pemilihan mahasiswa berprestasi program sarjana. Jakarta: Kementerian 
Riset dan Pendidikan Tinggi Indonesia.

Lemeshow, S., Hosmer, DW., Klarr, J., \& Lwanga, S.K. (1990). Adequacy of sample size. Chichester: John Wiley \& Sons Ltd.

Mailhot, B., \& Feeney, S.L. (2017). Perceived parental involvement and academic achievment of college students: The mediating role of academic self-concept. North American Journal of Psychology, 19(3), 685-708.

Mirnawati, L. B., \& Pribowo, F. S. (2017). Penerapan model pembelajaran SAVI untuk meningkatkan kemampuan berbicara mahasiswa PGSD FKIP Universitas Muhammadiyah Surabaya. Jurnal Pendidikan dan Pembelajaran Sekolah Dasar, 1(2), 144-152.

Parma, G. P. (2014). Softskill development sebagai konsep dalam kegiatan pengembangan program kemahasiswaan (studi pemetaan dan analisis program kemahasiswaan fakultas ekonomi dan bisnis). Seminar Nasional Riset Inovatif, 2, 285-292.

Purba, M. (2009). Analisis pengaruh kualitas pelayanan terhadap prestasi akademik mahasiswa perguruan tinggi X. Skripsi. Bogor: Institut Pertanian Bogor.

Purwanto, N. (2013). Psikologi pendidikan. Bandung: Remaja Rosdakarya.

Putri, K. P. (2014). Analisis faktor eksternal dan internal yang memengaruhi prestasi mahasiswa (studi kasus alumni program sarjana manajemen FEM IPB. Skripsi. Bogor: Institut Pertanian Bogor.

Monkey, S. (2017). Mengenal net promoter score. Diakses dari https://www.surveymonkey .com/ mp/ mengenal-net-promoter-score pada tanggal 1 November 2017.

Tambunan, H. (2011). Desain dan pengembangan model pembelajaran berbasis softskill. Jurnal Pendidikan Teknologi dan Kejuruan. 13(1), 8-14. 